\title{
Estimation of Heritability, Genetic Advance and Correlation for Marphological Traits in Spring Wheat
}

\section{Arshad Iqbal ${ }^{* *}$, Iftikhar Hussain Khalil ${ }^{1}$, Syed Mehar Ali Shah ${ }^{1}$ and Muhammad Sharif Kakar ${ }^{2}$}

\section{${ }^{1}$ Department of Plant Breeding and Genetics, The University of Agriculture, Peshawar, KPK, Pakistan; ${ }^{2}$ Agriculture Research} Institute, Sariab, Quetta, Pakistan.

Abstract | Heritability plays a pivotal role in selection. Breeders could predict the performance of crop plants by knowing the magnitude of heritability. An experiment was conducted using a set of spring wheat genotypes to estimate heritability for various plant traits during crop season 2014-15 at the University of Agriculture, Peshawar. The randomized complete block design with three replications was used in the experiment. Data were recorded on yield and some other important plant traits like days to heading (days), days to maturity (days), flag leaf area $\left(\mathrm{cm}^{2}\right)$, spike length $(\mathrm{cm})$, grains spike ${ }^{-1}$ (no.), grains weight spike ${ }^{-1}(\mathrm{~g})$, biological yield $\left(\mathrm{kg} \mathrm{ha}^{-1}\right)$ and grain yield $\left(\mathrm{kg} \mathrm{ha}^{-1}\right)$. Mean performance of genotypes showed that all the spring wheat genotypes performed well for all the traits. Spring wheat cultivar Tatara showed best performance for maturity, similarly, genotype SM12 performed well for grains spike ${ }^{-1}$ and grain weight spike ${ }^{-1}$, whereas, genotype SM4 performed well for grain yield. Relatively high heritability with low genetic advance was estimated for days to maturity, while moderate to high heritability coupled with genetic advance was recorded for other yield related traits. Correlation analysis showed that grain yield had strong positive phenotypic and genetic correlation with heading, maturity, flag leaf area and biological yield. Spring wheat genotype SM12 had best performance for grains spike ${ }^{-1}$ and grain weight spike ${ }^{-1}$ should be further tested at different location of Khyber Pakhtunkhwa for possible release as a new cultivar.

Received | April 05, 2016; Accepted | October 02, 2017; Published | November 19, 2017

*Correspondence | Arshad Iqbal, The University of Agriculture, Peshawar, KPK, Pakistan; Email: arshadiqbal@aup.edu.pk

Citation | Iqbal, A., I.H. Khalil, S.M.A. Shah and M.S. Kakar. 2017. Estimation of heritability, genetic advance and correlation for marphological traits in spring wheat. Sarbad Journal of Agriculture, 33(4): 674-679.

DOI | http://dx.doi.org/10.17582/journal.sja/2017/33.4.674.679

Keywords | Spring wheat, Variability, Heritability, Genetic advance, Genotypic and phenotypic correlation

\section{Introduction}

$\mathrm{P}$ akistan has diverse agro-ecological regions comprising both plains and mountains of Baluchistan, Punjab, Sindh, Khyber Pakhtunkhwa (KP), Azad Jammu and Kashmir and Gilgit-Baltistan. These regions include high precipitous valleys and irrigated plains. The environmental issues such as temperature fruitfulness status, soil distinctiveness and rainfall play a vital role in the varietal recital. Wheat is successfully grown in Khyber Pakhtunkhwa. It occupies $40 \%$ of the total cropped area and $60 \%$ of the area grown to cereals in the province. In 2013-14 the total area devoted to wheat cultivation in $\mathrm{KP}$ was 0.72 million ha, which produced 1.15 million tonnes of wheat with an average yield of $1590 \mathrm{~kg} / \mathrm{ha}$ (GoP, 2015). Improvement in wheat production is essential for future purposes because of ever increasing population pressure. We need to develop such varieties that fulfil our nutritional requirements. Breeding objectives for bread wheat include suitability of different maturity groups for early, mild, and late planting and also special importance are given on high yield, resistance to diseases, resistance to lodging, wide adaptation, better milling, baking and nutritional qualities. Heritability and genetic advance are important to plant 
breeders as they not only serve as predictive function of crop performance in a succeeding generation but also guide the breeder in selection. The magnitude of heritability is of paramount significance in selection because high heritability makes the selection process a straightforward job. However, the use of heritability alone in advance generations is not adequate to bring significant improvement through selection if not accompanied with sufficient amount of genetic advance. Therefore, heritability when coupled with genetic advance could further strengthen the effectiveness of selection which has been documented by many researchers like, Ghosh and Gulati (2001); Akbar et al. (2003); Iqbal et al. (2003). Sometimes direct selection of complex traits such as yield could be misleading. Therefore, selection based on the associations of traits with grain yield could improve the chances of success and hence, the goal of high productivity can be realized (Uddin et al., 2015). Keeping in view the significance of above facts, an experiment was conducted with specific objectives to; i) estimate genetic variability, heritability and genetic advance for spring wheat genotypes and ii) determine genetic and phenotypic associations among important traits.

\section{Materials and Methods}

Genetic materials and experimental site

This experiment was conducted at The University of Agriculture, Peshawar, Pakistan during 2014-15 in order to estimate heritability, genetic advance and correlation among various traits of 16 spring wheat genotypes (Table 1 ).

Table 1: List of spring wheat genotypes used in the study during 2014-15

$\begin{array}{llll}\text { S.\# } & \text { Genotypes } & \text { S.\# } & \text { Genotypes } \\ \text { 1. } & \text { SM1 } & 9 . & \text { SM2 } \\ \text { 2. } & \text { Suleman-96 } & 10 . & \text { Hasham-98 } \\ \text { 3. } & \text { SM4 } & 11 . & \text { SM10 } \\ \text { 4. } & \text { Haider-2k } & 12 . & \text { Narc-11 } \\ \text { 5. } & \text { SM12 } & 13 . & \text { SRN-09111 } \\ \text { 6. } & \text { Tatara } & 14 . & \text { Millat } \\ \text { 7. } & \text { NRL-0913 } & 15 . & \text { CT-09137 } \\ \text { 8. } & \text { Miraj-08 } & 16 . & \text { Bathoor }\end{array}$

\section{Climatic data}

This experiment was conducted at Peshawar-Khyber Pakhtunkhwa. Peshawar is located $331 \mathrm{~m}$ above the sea level with $34.0167^{\circ} \mathrm{N}$ latitude whereas, $71.583^{\circ}$
E longitude with an annual precipitation of $384 \mathrm{~mm}$. The annual temperatures ranged from to $12{ }^{\circ} \mathrm{C}$ to 40 ${ }^{\circ} \mathrm{C}$ (Table 2).

Table 2: Climatic characteristics of the experimental site

$\begin{array}{ll}\text { Longitude } & 71.583^{\circ} \mathrm{E} \\ \text { Latitude } & 34.017^{\circ} \mathrm{N} \\ \text { Altitude } & 331 \mathrm{~m} \\ \text { Annual rainfall } & 384 \mathrm{~mm} \\ \text { Temperature } & 40^{\circ} \mathrm{C} \text { max }, 12^{\circ} \mathrm{C} \text { min } \\ \text { Relative humidity } & 32-90 \% \\ \text { Soil type } & \text { Alkaline } \\ \text { Average } \mathrm{PH} & 7.2-9.1\end{array}$

\section{Experimental design and crop husbandry}

Experimental material was planted in randomized complete block design with three replications. Each genotype had three rows of $3 \mathrm{~m}$ length per replication while a distance of $30 \mathrm{~cm}$ between rows was maintained. Crop management including application of weedicides/fungicides, fertilizers, land preparation, sowing and hoeing, etc. were done as per routine practice for all the genotypes to minimize the environmental variance.

\section{Data recording and measurements}

Data were recorded on days to heading by calculating days from germination to head initiation, days to maturity by counting number of days from germination to physiological maturity, flag leaf area by measuring width and breadth of flag leaf, spike length by measuring the length of spike from bottom to tip without awns, grains spike ${ }^{-1}$ by counting grains in spike, grain weight spike ${ }^{-1}$ by weighing grains in a spike, biological yield by weighing the all the plants per plot and converted to $\mathrm{kg}$ per hectare and grain yield by weighing grains per plot and converted to $\mathrm{kg}$ hectare ${ }^{-1}$.

\section{Analysis of variance}

Field data obtained on all 16 spring wheat genotypes were analysed as per procedures of Gomez and Gomez (1984) for randomized complete block design. Protected least significant difference (LSD) test was also used for mean comparison of genotypes.

\section{Heritability, genetic advance and correlation}

Heritability (broad sense) was estimated by calculating genetic variance and phenotypic variance as used by Marwede et al. (2004). Genetic and phenotypic correlations among various traits were also computed 
by using procedures of Singh and Chaudhary (1985).

Heritability was calculated by using the following;

$$
H^{2}=\frac{V_{g}}{V_{p}}=\frac{V_{g}}{V_{g}+V_{e}}
$$

Where,

$\mathrm{V}_{\mathrm{G}}=$ Genetic variance; $\mathrm{V}_{\mathrm{P}}=$ Phenotypic variance; $\mathrm{V}_{\mathrm{E}}$ $=$ Error variance.

Genetic advance was calculated according to Allard's (1964) by the following formula;

$$
\text { Genetic advance }(\mathrm{GA})=\mathrm{i} \times \mathrm{H}^{2} \times \sqrt{V_{p}}
$$

Where,

$\mathrm{ix}=$ selection intensity for trait $\mathrm{x} ; \mathrm{H}^{2}=$ heritability for trait $x ; \sqrt{ } \rho=$ square root of the phenotypic variance of trait $x$. Selection intensity at $10 \%$ will be 1.76 was assumed in predicting direct selection response

\section{Results and Discussion}

\section{Variance and mean performance}

Mean square values revealed that genotypes had wide differences for days to maturity, days to heading, flag leaf area, spike length, grains spike, grain weight spike $^{-1}$, biological yield and grain yield (Table 3 ). These results confirmed the outcomes of Tesfaye et al. (2014), Haq et al. (2010), Singh et al. (2009) and Muhammad et al. (2001). Days to heading, an important character which contribute towards high yield. Early heading is desirable for wheat breeders because as a result, grain filling duration increases which ultimately results in high yield. The coefficient of variation $(\mathrm{CV})$ and determination $\left(\mathrm{R}^{2}\right)$ was $0.98 \%$ and 0.75 , respectively. Mean performance of wheat genotypes for days to heading varied from 113 to 120 days (Table 4). Genotype Suleman-96 exhibited minimum days to heading (113 days), whereas, maximum days were taken by genotype SM1 (120 days). Early maturity can also help in attaining maximum yield. $\mathrm{Co}^{-}$ efficient of determination and variation was 0.75 and 0.92, respectively. Average days to maturity among wheat genotypes ranged from 149 to 155 days (Table 4). Genotype Tatara had minimum days to maturity (149 days), while, it took 155 days for genotype SM1 to reach maturity which was maximum. Flag leaf area is considered to be the major yield contributing character due to its significant contribution in photosynthesis (Faisal and Tahir, 2014). Breeders usually love to have broad flag leaf area as broad leaves offer larger surface area for the sunlight to trap in as a result more photosynthates are produced which eventually append in grain yield. Coefficient of variation $(\mathrm{CV})$ and determination $\left(\mathrm{R}^{2}\right)$ for flag leaf area was $11.84 \%$ and 0.62 , respectively. Mean value for flag leaf area among wheat genotypes ranged from 21.54 to $35.33 \mathrm{~cm}^{2}(\mathrm{Ta}-$ ble 4). Minimum flag leaf area was recorded for genotype Suleman-96 $\left(21.54 \mathrm{~cm}^{2}\right)$, whereas, maximum leaf area was observed in genotype SM1 $\left(35.33 \mathrm{~cm}^{2}\right)$. Spike length is the prime yield contributing character which results in the production of more grains. Long spikes are more likely to bear more spikelets. Coefficient of variation and determination for spike length was $2.71 \%$ and 0.81 , respectively. Mean value for spike length ranged from 9 to $11 \mathrm{~cm}$ (Table 4). Short spike length was observed in genotype CT$09137(9 \mathrm{~cm})$, whereas, long spikes were observed in genotype SM2 $(11 \mathrm{~cm})$. Number of grains spike ${ }^{-1}$ is an important character. The coefficient of variation $(\mathrm{CV})$ and determination $\left(\mathrm{R}^{2}\right)$ for grains spike ${ }^{-1}$ was $7.97 \%$ and 0.63 , respectively. Average value for grains spike ${ }^{-1}$ varied from 41.06 to 52.33 (Table 4). Least number of grains spike ${ }^{-1}$ was recorded for genotype Miraj-08 (41.06 g), whereas, highest number of grains spike ${ }^{-1}$ was recorded for genotype SM12 (52.33 g). Coefficient of variation $(\mathrm{CV})$ and determination $\left(\mathrm{R}^{2}\right)$ for grain weight spike ${ }^{-1}$ was $12.08 \%$ and 0.55 , respectively. Means value for grain weight spike ${ }^{-1}$ ranged from 1.63 to $2.35 \mathrm{~g}$ (Table 4). Low grain weight spike ${ }^{-1}$ was recorded for genotype Millat (1.63 g), while highest grain weight was recorded for genotype SM12 (2.35 g). Average biological yield ranged from 7024 to 9937 $\mathrm{kg} \mathrm{ha}^{-1}$ (Table 4). Minimum biological yield was recorded for genotype Miraj-08 (7024 kg ha-1), while, genotype NRL-0913 exhibited maximum biological yield $\left(9937 \mathrm{~kg} \mathrm{ha}^{-1}\right)$. Grain yield is prime objective of any crop improvement programme. Plant breeders strive to get the plants with maximum seed yield. The coefficient of variation $(\mathrm{CV})$ and determination $\left(\mathrm{R}^{2}\right)$ for grain yield was $11.50 \%$ and 0.57 , respectively. Mean grain yield ranged from 2609 to $3713 \mathrm{~kg}$ $\mathrm{ha}^{-1}$ (Table 4). Minimum grain yield was recorded for genotype Miraj-08 (2609 $\mathrm{kg} \mathrm{ha}^{-1}$ ), whereas, maximum grain yield was given by genotype SM4 (3713 $\left.\mathrm{kg} \mathrm{ha} \mathrm{a}^{-1}\right)$. The coefficient of variation $(\mathrm{CV})$ and determination $\left(\mathrm{R}^{2}\right)$ for harvest index was $2.76 \%$ and 0.90 , respectively.

\section{Heritability (BS), genetic advance \& correlation analysis}

Generally, values of genotypic correlations coefficients 
Table 3: Mean squares table for wheat characters evaluated during 2015.

$\begin{array}{llllll}\text { Parameters } & \begin{array}{l}\text { Replications } \\ (\mathbf{d f = 2 )}\end{array} & \begin{array}{l}\text { Genotypes } \\ \mathbf{( d f = 1 5 )}\end{array} & \begin{array}{l}\text { Error } \\ \mathbf{( d f = 3 0 )}\end{array} & \begin{array}{l}\text { CV } \\ \mathbf{( \% )}\end{array} & \mathbf{R}^{\mathbf{2}} \\ \text { Days to heading (days) } & 2.43 & 8.09^{* *} & 1.34 & 0.98 & 0.75 \\ \text { Days to maturity (days) } & 3.56 & 11.50^{* *} & 1.98 & 0.92 & 0.75 \\ \text { Flag leaf area } & 13.19 & 39.71^{* *} & 12.35 & 11.84 & 0.62 \\ \text { Spike length } & 0.05 & 0.67^{* *} & 0.07 & 2.71 & 0.81 \\ \text { Grains spike- } & 3.60 & 50.66^{* *} & 14.53 & 7.97 & 0.63 \\ \text { Grain weight spike-1 } & 0.11 & 0.11^{*} & 0.05 & 12.08 & 0.55 \\ \text { Biological yield } & 3423 & 2651^{*} & 1045 & 12.69 & 0.56 \\ \text { Grain yield } & 8388 & 3385^{*} & 1292 & 11.50 & 0.57\end{array}$

Note: ***=Significant at $5 \%$ and $1 \%$ probability level, respectively

Table 4: Means for days to heading, days to maturity, flag leaf area, plant height and spike length of 16 wheat genotypes evaluated at University of Agriculture, Pesharwar during 2015

\begin{tabular}{|c|c|c|c|c|c|c|c|c|}
\hline Genotype & $\begin{array}{l}\text { Days to } \\
\text { heading } \\
\text { (days) }\end{array}$ & $\begin{array}{l}\text { Days to } \\
\text { maturity } \\
\text { (days) }\end{array}$ & $\begin{array}{l}\text { Flag leaf } \\
\text { Area } \\
\left(\mathrm{cm}^{2}\right)\end{array}$ & $\begin{array}{l}\text { Spike } \\
\text { Length } \\
(\mathrm{cm})\end{array}$ & $\begin{array}{l}\text { Grains } \\
\text { spike }^{-1} \\
\text { (no.) }\end{array}$ & $\begin{array}{l}\text { Grain } \\
\text { weight } \\
\text { spike }^{-1}(g)\end{array}$ & $\begin{array}{l}\text { Biological } \\
\text { Yield } \\
\left(\mathbf{k g ~ h a}^{-1}\right)\end{array}$ & $\begin{array}{l}\text { Grain } \\
\text { Yield (kg } \\
\left.\text { ha' }^{-1}\right)\end{array}$ \\
\hline SM1 & 120.00 & 155.33 & 35.33 & 9.66 & 49.20 & 1.96 & 8579 & 3426 \\
\hline SM2 & 119.00 & 154.00 & 31.29 & 11.07 & 52.26 & 2.06 & 9048 & 3338 \\
\hline SM4 & 119.00 & 154.66 & 34.07 & 10.35 & 47.40 & 2.04 & 8715 & 3713 \\
\hline SM10 & 118.00 & 153.66 & 33.74 & 10.34 & 51.40 & 1.83 & 7826 & 3271 \\
\hline SM12 & 117.33 & 152.66 & 32.53 & 10.54 & 52.33 & 2.35 & 7123 & 2856 \\
\hline SRN-09111 & 118.33 & 152.33 & 31.86 & 10.84 & 51.10 & 2.01 & 9456 & 3473 \\
\hline NRL-09111 & 120.00 & 153.66 & 28.99 & 10.20 & 41.36 & 1.91 & 9937 & 3473 \\
\hline CT-09137 & 118.66 & 154.33 & 30.48 & 9.43 & 46.63 & 2.02 & 8641 & 3515 \\
\hline SULEMAN-96 & 113.66 & 150.33 & 21.54 & 9.92 & 42.76 & 1.75 & 7036 & 2782 \\
\hline HASHAM-98 & 117.33 & 151.00 & 29.62 & 10.04 & 52.6 & 1.83 & 7777 & 2930 \\
\hline HAIDER-2K & 119.66 & 150.33 & 27.04 & 10.50 & 48.26 & 1.79 & 8481 & 3019 \\
\hline NARC-11 & 118.33 & 150.00 & 30.05 & 9.93 & 47.80 & 1.72 & 7728 & 2936 \\
\hline TATARA & 116.33 & 149.33 & 29.22 & 9.54 & 51.56 & 2.13 & 7061 & 2703 \\
\hline MILLAT & 117.66 & 150.33 & 24.60 & 9.74 & 41.80 & 1.61 & 7283 & 2852 \\
\hline MIRAJ-08 & 116.33 & 154.33 & 26.04 & 10.03 & 41.06 & 1.63 & 7024 & 2609 \\
\hline BATHOOR & 117.00 & 151.66 & 28.41 & 9.75 & 47.80 & 1.94 & 7196 & 3100 \\
\hline $\operatorname{LSD}(0.05)$ & 1.93 & 2.34 & 5.86 & 0.45 & 6.35 & 0.38 & 1705 & 599.5 \\
\hline
\end{tabular}

Table 5: Variance components E beritability of different characters

\begin{tabular}{|c|c|c|c|c|}
\hline Traits. & $\mathbf{V g}$ & $V_{p}$ & $\mathbf{h}^{2}{ }_{(\mathrm{BS})}$ & GA \\
\hline Days to heading & 2.25 & 1.34 & 62.67 & 1.28 \\
\hline Days to maturity & 3.17 & 1.98 & 61.55 & 1.52 \\
\hline Flag leaf area & 9.12 & 12.35 & 42.47 & 2.63 \\
\hline Spike length & 0.19 & 0.07 & 74.07 & 0.34 \\
\hline Grains spike ${ }^{-1}$ & 12.04 & 14.53 & 45.13 & 3.03 \\
\hline Grain weight spike ${ }^{-1}$ & 0.02 & 0.05 & 28.37 & 0.11 \\
\hline Biological yield & 535.3 & 1045 & 33.88 & 19.28 \\
\hline Grain yield & 697.6 & 1292 & 35.07 & 22.19 \\
\hline
\end{tabular}

were higher than their subsequent phenotypic correlations showing important role of genetic factors in the associations of these traits. Grain yield had significant positive phenotypic and genotypic correlation with days to heading, days to maturity, flag leaf area and biological yield (Table 6) implying the true associations of these traits with grain yield. These results were in accordance with the findings of Uddin et al. (2015), who reported significant positive association of grain yield with days to heading, flag leaf area and grains weight spike ${ }^{-1}$. Similar findings have also been reported earlier by Khan et al. (2007) and Masood et al. (2005) in their wheat germplasm. Heritability 
Table 6: Genotypic $(G)$ and phenotypic $(P)$ correlation between different yield and yield components

\begin{tabular}{|c|c|c|c|c|c|c|c|c|}
\hline Traits & & DM & FLA & SL & G/S & GW/S & BY & GY \\
\hline Days to heading & $\begin{array}{l}P \\
G\end{array}$ & $\begin{array}{l}\mathbf{0 . 3 9 ^ { * * }} \\
0.47^{*}\end{array}$ & $\begin{array}{l}\mathbf{0 . 5 2} 2^{* *} \\
0.64^{* *}\end{array}$ & $\begin{array}{l}\mathbf{0 . 1 7} \\
0.26\end{array}$ & $\begin{array}{l}\mathbf{0 . 1 1} \\
0.17\end{array}$ & $\begin{array}{l}-\mathbf{0 . 0 8} \\
0.19\end{array}$ & $\begin{array}{l}\mathbf{0 . 4 9 ^ { * * }} \\
0.77^{* *}\end{array}$ & $\begin{array}{l}\mathbf{0 . 4 8} \mathbf{8}^{* *} \\
0.71^{* *}\end{array}$ \\
\hline Days to maturity & $\begin{array}{l}\mathrm{P} \\
\mathrm{G}\end{array}$ & -- & $\begin{array}{l}\mathbf{0 . 4 0 ^ { * * }} \\
0.58^{* *}\end{array}$ & $\begin{array}{l}\mathbf{0 . 2 4} \\
0.18\end{array}$ & $\begin{array}{l}\mathbf{0 . 0 2} \\
-0.03\end{array}$ & $\begin{array}{l}\mathbf{0 . 1 6} \\
0.25\end{array}$ & $\begin{array}{l}\mathbf{0 . 2 7 ^ { * }} \\
0.47\end{array}$ & $\begin{array}{l}\mathbf{0 . 4 2} 2^{* *} \\
0.64^{* *}\end{array}$ \\
\hline Flag leaf area & $\begin{array}{l}\mathrm{P} \\
\mathrm{G}\end{array}$ & & -- & $\begin{array}{l}\mathbf{0 . 2 3} \\
0.25\end{array}$ & $\begin{array}{l}\mathbf{0 . 4 7 ^ { * }} \\
0.63^{* * *}\end{array}$ & $\begin{array}{l}\mathbf{0 . 3 6} \\
0.60^{*}\end{array}$ & $\begin{array}{l}\mathbf{0 . 3 0 ^ { * }} \\
0.43^{*}\end{array}$ & $\begin{array}{l}\mathbf{0 . 5 3 ^ { * * }} \\
0.64^{* *}\end{array}$ \\
\hline Spike length & $\begin{array}{l}\mathrm{P} \\
\mathrm{G}\end{array}$ & & & -- & $\begin{array}{l}\mathbf{0 . 3 8} 8^{* *} \\
0.36\end{array}$ & $\begin{array}{l}\mathbf{0 . 2 7 ^ { * }} \\
0.29\end{array}$ & $\begin{array}{l}\mathbf{0 . 2 9 ^ { * }} \\
0.42^{*}\end{array}$ & $\begin{array}{l}\mathbf{0 . 1 7} \\
0.24\end{array}$ \\
\hline Grains spike $^{-1}$ & $\begin{array}{l}\mathrm{P} \\
\mathrm{G}\end{array}$ & & & & -- & $\begin{array}{l}\mathbf{0 . 5 6} \\
0.64^{* * *}\end{array}$ & $\begin{array}{l}\mathbf{0 . 0 8} \\
0.06\end{array}$ & $\begin{array}{l}\mathbf{0 . 1 1} \\
0.14\end{array}$ \\
\hline Grains weight spike ${ }^{-1}$ & $\begin{array}{l}\mathrm{P} \\
\mathrm{G}\end{array}$ & & & & & -- & $\begin{array}{l}\mathbf{0 . 1 3} \\
0.24\end{array}$ & $\begin{array}{l}\mathbf{0 . 1 2} \\
0.36\end{array}$ \\
\hline Biological yield & $\begin{array}{l}\mathrm{P} \\
\mathrm{G}\end{array}$ & & & & & & -- & $\begin{array}{l}\mathbf{0 . 7 5 ^ { * * }} \\
0.83^{\text {*** }}\end{array}$ \\
\hline
\end{tabular}

estimates and variance components for various characters are shown in Table 5. Analysis revealed that characters displayed less to high broad sense heritability and genetic advance, ranged from 33.88 to $80.66 \%$ and 0.11 to 22.19 , respectively (Table 5). Less broad sense heritability (28.37) and genetic advance (0.11) was displayed by grain weight spike ${ }^{-1}$. The genotypic coefficient of variability $\left(\mathrm{v}_{\mathrm{g}}\right)$ for grain weight spike $^{-1}$ was 0.02 and environmental coefficient of variability $\left(\mathrm{V}_{\mathrm{e}}\right)$ for grain weight spike ${ }^{-1}$ was 0.05 , which indicates more influence of environmental factors on genotype for grain weight spike ${ }^{-1}$, hence, selection for this trait will not be easy and effective due to presence of non-additive (dominance and epistasis) genes. Moderate broad sense heritability and genetic advance was disclosed by flag leaf area and grains spike ${ }^{-1}$ (45.13) (Table 5), which indicated that the influence of environmental variance is more than the genotypic variance, hence delayed selection might be effective for these traits. Whereas, moderate broad sense heritability coupled with high genetic advance was recorded for biological yield and grain yield (Table 5), indicating that these traits were mainly controlled by additive type of genes and selection in early generation would be effective. Whereas, high heritability coupled with low genetic advance was observed for days to heading, days to maturity and spike length (Table 5), indicating important role genetic variance, hence, direct selection for these traits could bear desirable results. The present results were in accordance with those previously reported by Yousif et al. (2015), Ashfaq et al. (2014), Ijaz et al. (2013), Kashif and Khaliq (2004) and Singh et al. (2009) who reported moderate to high heritability for the said characters in wheat genotypes.

\section{Conclusions}

Results displayed significant differences among spring wheat genotypes for the studied characters. All attributes exhibited considerable differences for genotypes having low to high broad sense heritability and genetic advance. Hence, genotypes having high heritability could be used in perfecting the important attributes. Strong phenotypic and genotypic association of grain yield was observed with days to heading, days to maturity, flag leaf area and biological yield. Based on the study of phenotypic and genotypic association traits like days to maturity, days to heading, flag leaf area and biological yield could be used as selection parameter to improve grain yield. Overall, genotype SM4 performed exceptionally well among all the genotypes used in the study and hence, could be considered for general cultivation in the agro-climatic conditions of Khyber Pakhtunkhwa.

\section{Author's Contribution}

Arshad Iqbal concieved the idea, designed the experiments and conducted the whole research. Iftikhar Hussain Khalil was the main supervisor who provided technical input and support at every step. Syed $\mathrm{Me}-$ har Ali Shah helped in manuscript modification and technical improvments. Muhammad Sharif Kakar providence of hermplasm.

\section{References}

Allard, R. 1964. Principles of plant breeding. John 
Wiley and Sons. Inc. New York, London.

Akbar, M., T. Mahmood, M. Yaqub, M. Anwar, M.

Ali and N. Iqbal. 2003. Variability, correlation and path coefficient studies in summer mustard (Brassica juncea L.). Asian J. Plant Sci. 2(9): 696-698. https://doi.org/10.3923/ ajps.2003.696.698

Ashfaq, S., H.M. Ahmad, S.I. Awan, S.A. Kang, M. Sarfraz and M.A. Ali. 2014. Estimation of genetic variability, Heritability and Correlation for some morphological traits in spring wheat. J. Biol. Agric. Healthcare. 4(5):10-16.

Faisal, M., and M.A. Tahir. 2014. Flag leaf characteristics and relationship with grain yield and grain protein percentage for three cereals. J. Med. Plants Studies. 2(5):1-7.

Gomez, K.A., and A.A. Gomez. 1984. Statistical procedures for agricultural research $\left(2^{\text {nd }}\right.$ ed. $)$. John Wiley and Sons Inc. New York. USA.

Ghosh, S.K., and S.C. Gulati. 2001. Genetic variability and association of yield components in Indian mustard. Crop Res. 21(3): 345-349.

Government of Pakistan, 2015. Pakistan Bureau of Statistics, Agricultural Statistics, Islamabad, Pakistan.

Haq, W., M. Munir and Z. Akram. 2010. Estimation of interrelationships among yield and yield related attributes in wheat lines. Pak. J. Bot. 42(1): 567-573.

Iqbal, S., T. Mahmood, Tahira, M. Ali, M. Anwar and M. Sarwar. 2003. Path coefficient analysis in different genotypes of soybean (Glycine max L.). Pak. J. Biol. Sci. 6(12): 1085-1087. https:// doi.org/10.3923/pjbs.2003.1085.1087

Ijaz, F., I. Khaliq, M.T. Shahzad and B. Salam.2013, Computation of heritability of yield and some morphological traits in $\mathrm{F} 2$ population of spring wheat (Triticum aestivum L.) Intl. J. Modern Agric. 2(3):102-107.

Kashif, M., and I. Khaliq. 2004. Heritability, correlation and path coefficient analysis for some metric traits in wheat. Intl. J. Agric. Biol.
69(1):138-142.

Khan, M.M., R.D. Khan and M.A. Rabbani. 2007. Evaluation of bread wheat (Triticum aestivum L.) germplasm for its variability for different traits. Gomal Uni. J. Res. 23(2):32-38.

Muhammad, F., H. Daniel, K. Shehzad and H. Khan. 2001. Heritability estimates for yield and its components in wheat. Sarhad J. Agric. 17(2):227-234.

Marwede, V., A. Schierholt, C. Möllers and H.C. Becker. 2004. Genotype x environment interactions and heritability of tocopherol contents in canola. Crop Sci. 44(3): 728-731. https://doi.org/10.2135/cropsci2004.0728 https://doi.org/10.2135/cropsci2004.7280

Masood, M.S., A. Javaid, M.A. Rabbani and R. Anwar. 2005. Phenotypic diversity and traits association in bread wheat (Triticum aestivum L.) land races from Baluchistan, Pakistan. Pak. Bot. 37(4): 949-957.

Singh, R.K., and B.D. Chaudhary. 1985. Biometrical methods in quantitative genetic analysis. Kalyani Publishers, New Delhi, Ludhiana, India. P-39-78.

Singh, B.D., P.R, Majumda and K.K Prassad 2009. Heritability studies in timely sown irrigated wheat. J. Appl. Biol. 9(2): 105-107.

Tesfaye, T., T. Genet and T. Deslegn. 2014. Genetic variability, heritability and genetic diversity of bread wheat (Triticum aestivum L.) genotype in Western Amhara region, Ethiopia. Wudpecker J. Agri. Res. 3(1):26-43.

Uddin, F., F. Mohammad and S. Ahmed. 2015. Genetic Divergence in wheat Recombinant Inbred lines for yield and yield components. Am-Euras. J. Agric. Environ. Sci. 15(9): 18541859.

Yousif, S.A, H. Jasim, A.R. Abbas, D.P. Yousif. 2015. Some Yield parameters of wheat genotypes. World Acad. Sci. Engg. Tech. Intl. J. Biol. Biomol. Agric. Food Biotec. Engg. 9(3): 323-326. 